\title{
The Genetic and Clinical Significance of Fetal Hemoglobin Expression in Sickle Cell Disease
}

\author{
Adekunle Adekile \\ Department of Pediatrics, Faculty of Medicine, Kuwait University, Kuwait City, Kuwait
}

\section{Highlights of the Study}

- Sickle cell disease is clinically heterogeneous.

- $\mathrm{HbF}$ is an important genetic modulating factor; however, several quantitative trait loci modify its expression.

- Kuwaiti patients uniformly express elevated $\mathrm{HbF}$ levels, but the factors responsible for this are not clear and may be different from published reports.

- This review addresses these issues in an in-depth and critical manner.

\section{Keywords}

Sickle cell disease $\cdot$ Fetal hemoglobin

\begin{abstract}
Sickle cell disease (SCD) is phenotypically heterogeneous. One major genetic modifying factor is the patient's fetal hemoglobin ( $\mathrm{HbF}$ ) level. The latter is determined by the patient's $\beta$-globin gene cluster haplotype and cis- and transacting single nucleotide polymorphisms (SNPs) at other distant quantitative trait loci (QTL). The Arab/India haplotype is associated with persistently high $\mathrm{HbF}$ levels and also a relatively mild phenotype. This haplotype carries the Xmn 1 (C/T) SNP, rs7482144, in the HBG2 locus. The major identified trans-acting QTL contain SNPs residing in the BCL11A on chromosome 2 and the HMIP locus on chromosome 6 . These collectively account for $15-30 \%$ of $\mathrm{HbF}$ expression in different world populations and in patients with SCD or
\end{abstract}

karger@karger.com www.karger.com/mpp

Karger $\stackrel{\text { ' }}{5}$

GOPEN ACCESS
(C) 2020 The Author(s)

Published by S. Karger AG, Basel

This is an Open Access article licensed under the Creative Commons Attribution-NonCommercial-4.0 International License (CC BY-NC) (http://www.karger.com/Services/OpenAccessLicense), applicable to the online version of the article only. Usage and distribution for commercial purposes requires written permission. $\beta$-thalassemia. Patients with SCD in Kuwait and Eastern Saudi Arabia uniformly carry the Arab/India haplotype, but despite this, the HbF and clinical phenotypes show considerable heterogeneity. Pain episodes and avascular necrosis of the femoral head are particularly common, but severe bacterial infections, stroke, priapism, and leg ulcers are uncommon. Moreover, the HbF modifiers appear to be different; the reported BCL11A and HMIP SNPs appear to play insignificant roles. There are probably novel modifiers to be discovered in this population. This review examines the common clinical phenotypes in Kuwaiti patients with elevated $\mathrm{HbF}$ and the available information on $\mathrm{HbF}$ modifiers. The response of the patients to hydroxyurea is discussed. The presentation of patients with other sickle compound heterozygotes (S $\beta$ thal and $\mathrm{HbSD}$ ), vis-à-vis their $\mathrm{HbF}$ levels, is also addressed critically.

(c) 2020 The Author(s)

Published by S. Karger AG, Basel
Adekunle Adekile

Department of Pediatrics, Kuwait University

Jabriya

Kuwait City 13110 (Kuwait) adekunle.adekile@ku.edu.kw 


\section{Introduction}

The sickle cell disease (SCD) clinical phenotype is uniquely heterogeneous, with several genetic and environmental modifying factors playing significant roles [1$4]$. Among the former, fetal hemoglobin $(\mathrm{HbF})$ is the most recognized, while others include coexistent $\alpha$-thalassemia trait and the $\beta$-globin gene cluster haplotype. The focus of the current review is the role of $\mathrm{HbF}$ in this regard, especially as it is reflected among Kuwaiti and Gulf Arab patients.

Since Pauling's description of SCD as the first molecular disease in 1949 [5], there has been rapid accumulation of knowledge about the genotype/phenotype correlations in SCD. This was enhanced with the advent of recombinant DNA technology and restriction fragment length polymorphisms in the mid-1970s, followed by advances in genomic studies. Thus, we know more about the molecular characterization of SCD than any other disease and, in fact, the whole field of molecular medicine is derived from this knowledge.

\section{Hemoglobin Structure and Function}

The hemoglobin molecule is a tetrameric protein consisting of 2 pairs of polypeptide globin chains, with each of the 4 chains attached to a heme group composed of porphyrin and an Fe atom. Because of the differences in oxygen requirements at various developmental stages, different hemoglobins are synthesized for optimal oxygen delivery to the tissues [6]. Thus, while the normal adult hemoglobin is composed of $\alpha_{2} \beta_{2}$ chains, $\mathrm{HbF}$ is made up of $\alpha_{2} \gamma_{2}$ and embryonic hemoglobins are Gower $1\left(\zeta_{2} \varepsilon_{2}\right)$, Portland $\left(\zeta_{2} \gamma_{2}\right)$, and Gower $2\left(\alpha_{2} \varepsilon_{2}\right)$.

The functional integrity of the hemoglobin molecule is dependent on the primary sequence of the amino acids in the globin chains. The secondary, tertiary, and quaternary structures are determined by the contacts between the chains (the $\alpha_{1}-\beta_{1}$ and $\alpha_{1}-\beta_{2}$ contacts) and between each of the $2 \alpha$ and $2 \beta$ chains and the 4 heme groups [710]. Other factors that influence oxygen transport include the effects of $\mathrm{CO}_{2}$ and different affinities for 2,3-bisphosphoglycerate. Thus, the classical sigmoid shape of the oxygen dissociation curve promotes uptake of oxygen in the high oxygen tensions available in the lungs and it is readily released in the lower tensions encountered in the tissues.

\section{Genetic Control of Globin Synthesis}

The genetic control of globin synthesis resides in loci on chromosome 11 for $\beta$-like genes and chromosome 16 for $\alpha$-like genes (Fig. 1) [6]. The former are arranged in the order in which they are transcribed at different developmental stages: $5^{\prime}-{ }_{-}{ }_{-}{ }^{\mathrm{G}} \gamma_{-}{ }^{\mathrm{A}} \gamma-\psi \beta-\delta-\beta-3^{\prime}$. In the same fashion, the $\alpha$-like globin genes are arranged: $5^{\prime}-\zeta-\psi \zeta-\psi \alpha_{1^{-}}$ $\alpha_{2}-\alpha_{1}-3^{\prime}$. It should be noted that $\psi \beta, \psi \zeta$, and $\psi \alpha$ are pseudogenes of no known functional significance. The globin genes contain conserved elements, which are common to all mammals and are located in different regions of the cluster and play critical roles in the transcription process. There are also several sequences that constitute regulatory elements within each gene. In addition, each cluster has "master" regulatory sequences, which are referred to as the locus control region for the $\beta$-globin cluster, and for the a genes, there is the HS 40 , located $40 \mathrm{~kb}$ upstream.

The interactions of enhancers, elements within the gene themselves, and the master control regions ensure the control of the erythroid-specific gene expression, leading to the production of specific types of globin chains for each developmental stage. Thus, the early embryonic hemoglobins give way to $\mathrm{HbF}$ production within the first 6-8 weeks of prenatal life (Fig. 2). In the normal newborn, $\mathrm{HbF}$ is predominant at birth, but its level rapidly declines such that by the 6 th month of life, it forms $<1 \%$ of the total hemoglobin. However, there are many situations when the high level persists to varying degrees.

\section{Sickle Cell Disease}

The abnormal HbS is inherited in an autosomal recessive fashion. The homozygous condition, HbSS, is the most common and severe form of SCD, and it is also referred to as sickle cell anemia. However, $\mathrm{HbS}$ can coexist with other abnormal $\beta$-globin variants, with which it can copolymerize. Examples of these compound heterozygotes are S $\beta$ thalassemia, SC, SD, SE, and SOArab, which are all in the SCD spectrum. The abnormality in $\mathrm{HbS}$ is a substitution of valine for glutamic acid at the 6th amino acid position in the $\beta$-globin chain. This alters the physicochemical properties of the hemoglobin molecule, such that in the deoxygenated state, HbS is less soluble and forms long fibers. This polymerization is triggered by hydrophobic bonds between the valine of $1 \mathrm{HbS}$ molecule and alanine, phenylalanine, and leucine from an adjacent $\mathrm{HbS}$ molecule. The polymers distort the shape of the 


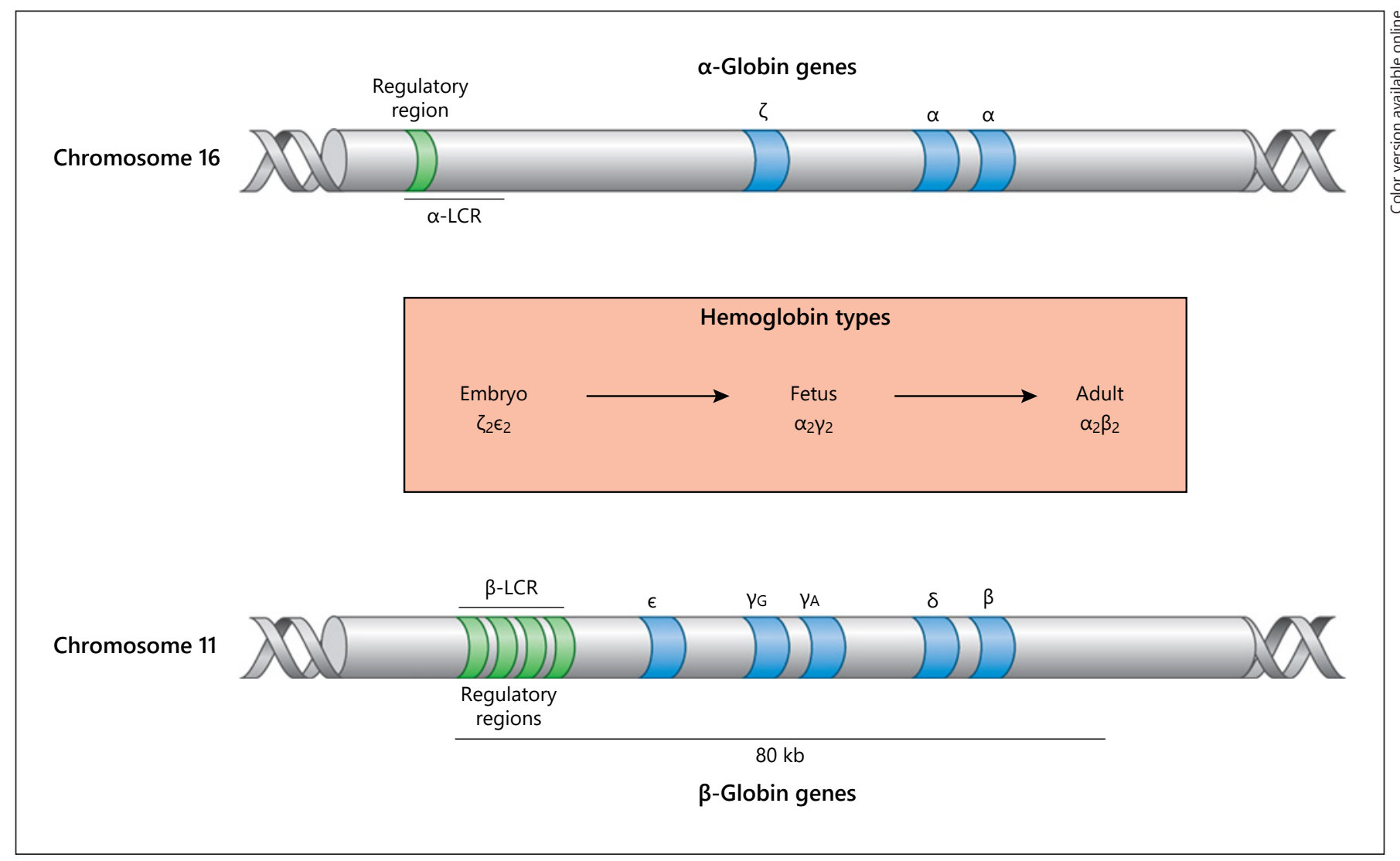

Fig. 1. Structure and arrangement of alpha and beta globin genes on chromosomes 11 and 16, showing the regulatory regions.

Fig. 2. Hemoglobin switching from embryonic to adult life. From: Wood WG. Haemoglobin synthesis during human fetal development. Br Med Bull. 1976;32:282 [11].

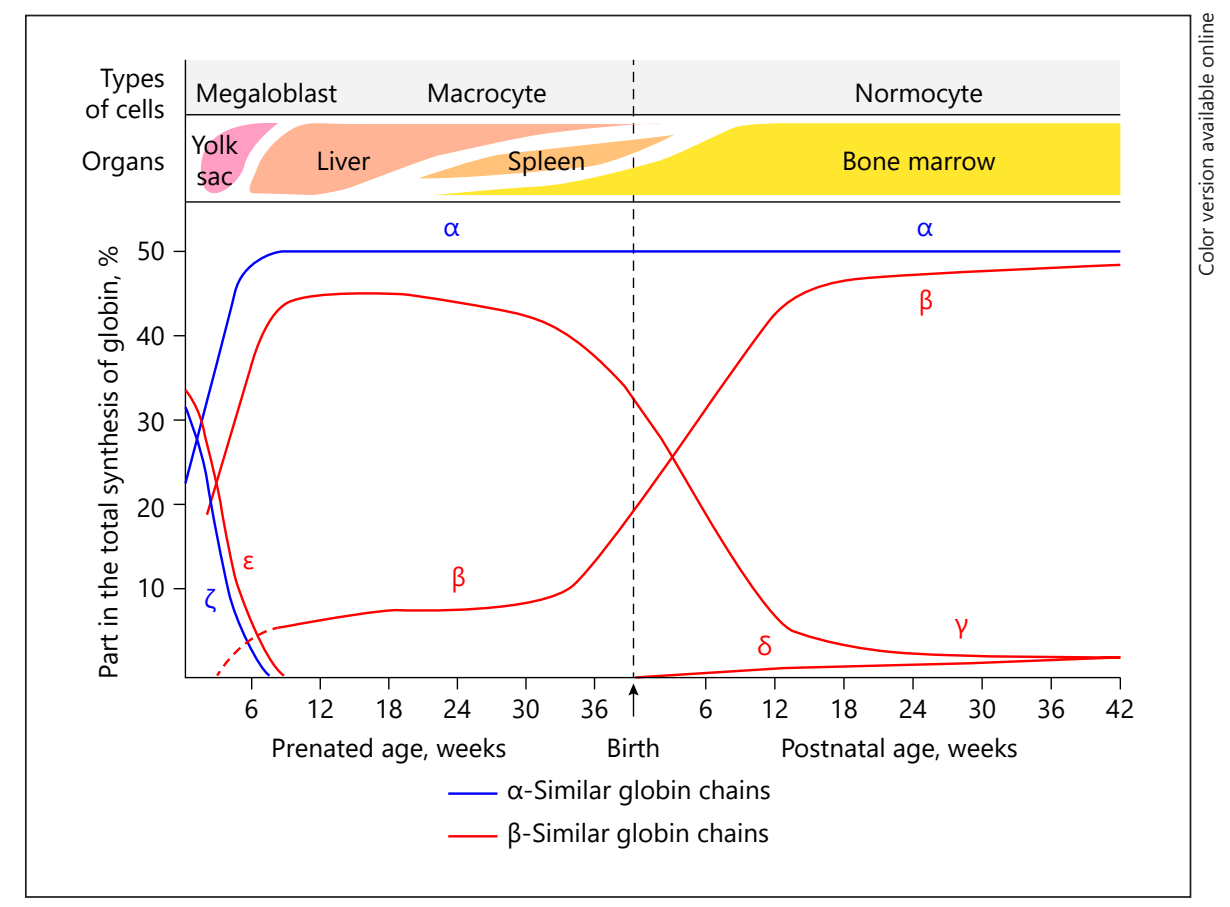




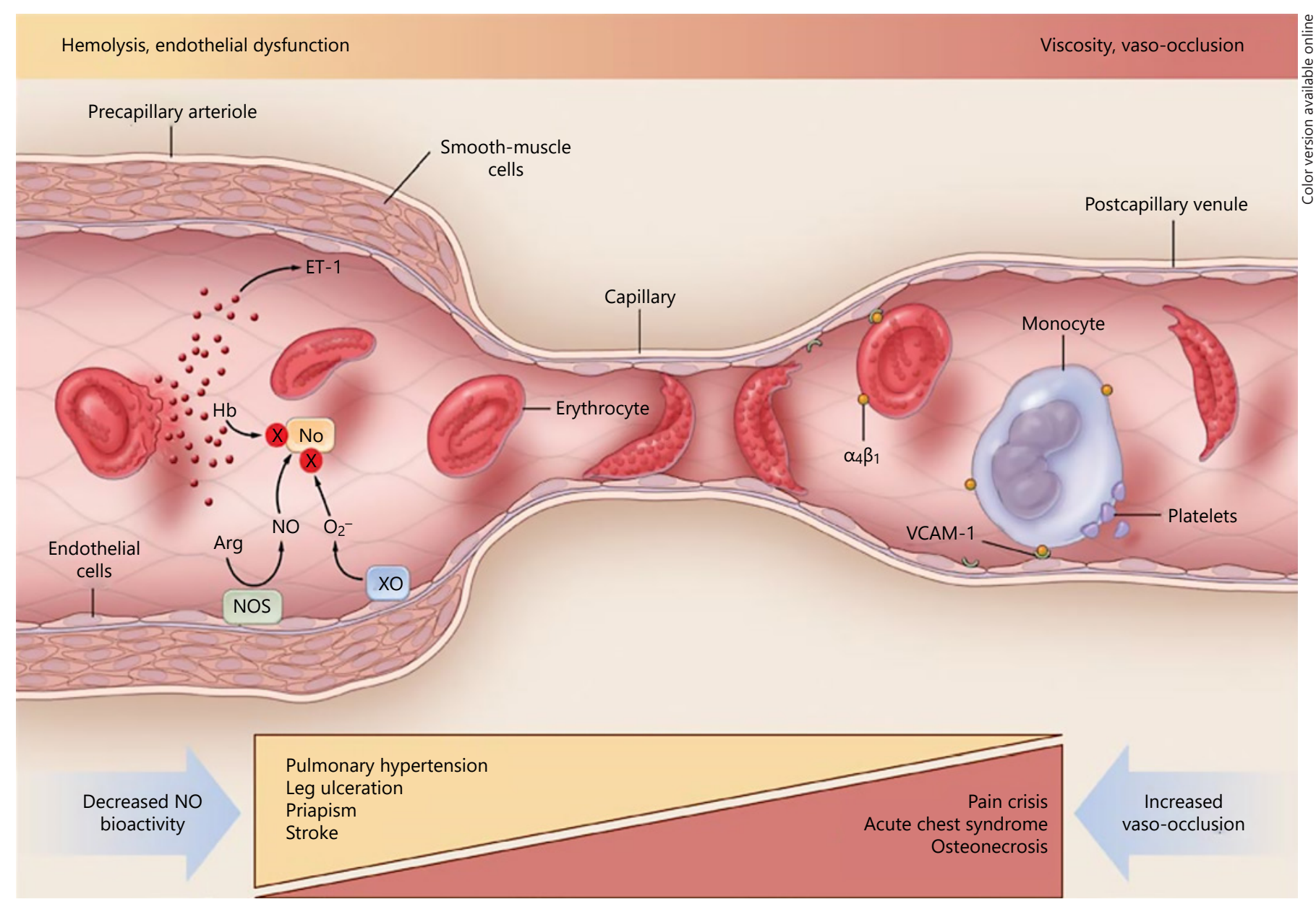

Fig. 3. The 2 major subphenotypes of sickle cell disease. From: Kato GJ, Gladwin MT, Steinberg MH. Deconstructing sickle cell disease: reappraisal of the role of hemolysis in the development of clinical subphenotypes. Blood Rev. 2007;21(1):37-47 [12].

RBCs into sickle forms. The cells become rigid and less deformable, making it difficult to navigate the small blood capillaries, hence the recurrent vaso-occlusion that characterizes the disease. The second major consequence is that the life span of the RBC is shortened with consequent chronic hemolysis.

The release of free heme sets off a cascade of inflammatory processes within the intravascular space, which culminates in nitric oxide (NO) depletion $[12,13]$. NO is a critical vasodilator produced mainly by endothelial cells from its obligatory substrate, L-arginine. The level of the latter is reduced in SCD because of the action of arginase, which is released by lysed red blood cells [14]. This impaired NO availability in SCD leads to vasoconstriction, platelet activation, upregulation of adhesion molecules, generation of thrombin, and proliferation of endothelial intima, culminating in arterial stenosis and eventual oc- clusion. In addition, there is activation of neutrophils, monocytes, and macrophages [15].

Thus, there are 2 defined subphenotypes of SCD, one related to the endothelial dysfunction secondary to hemolysis and the other related to vaso-occlusion and viscosity (Fig. 3) [12]. While these are 2 ends of a spectrum, there is no clear distinction between the 2 and they tend to be a continuum. However, endothelial dysfunctionis associated with pulmonary hypertension, stroke, leg ulcers, and priapism. The relevant biomarkers of hemolysis include free heme, reticulocyte count, serum lactate dehydrogenase, and bilirubin. On the other hand, the vaso-occlusion subphenotype is associated with recurrent painful episodes, acute chest syndrome (ACS), and osteonecrosis. Predisposing to this subphenotype are increased blood viscosity, resulting from high hematocrit that would be seen in SCD patients with $\alpha$-thalassemia 


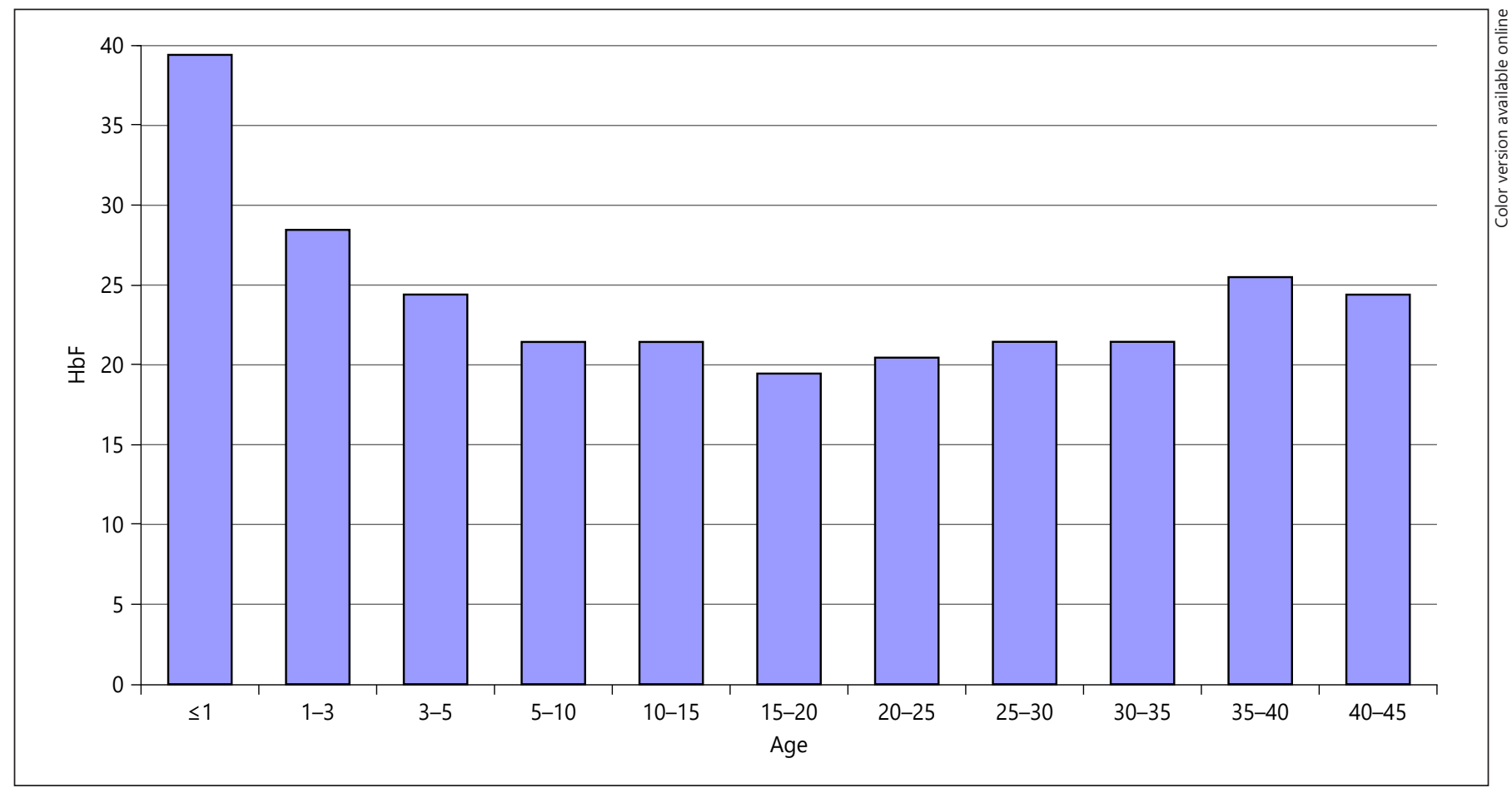

Fig. 4. Age distribution of fetal hemoglobin $(\mathrm{HbF})$ in Kuwaiti patients with sickle cell disease. From: Adekile, AD. Limitations of $\mathrm{Hb} \mathrm{F}$ as a phenotypic modifier in sickle cell disease: study of Kuwaiti Arab patients. Hemoglobin. 2011;5:607 [47].

Fig. 5. Distribution of fetal hemoglobin ( $\mathrm{HbF}$ ) among 268 Kuwaiti patients (adult and pediatric) with sickle cell disease. Adekile AD, 2019 (Unpublished).

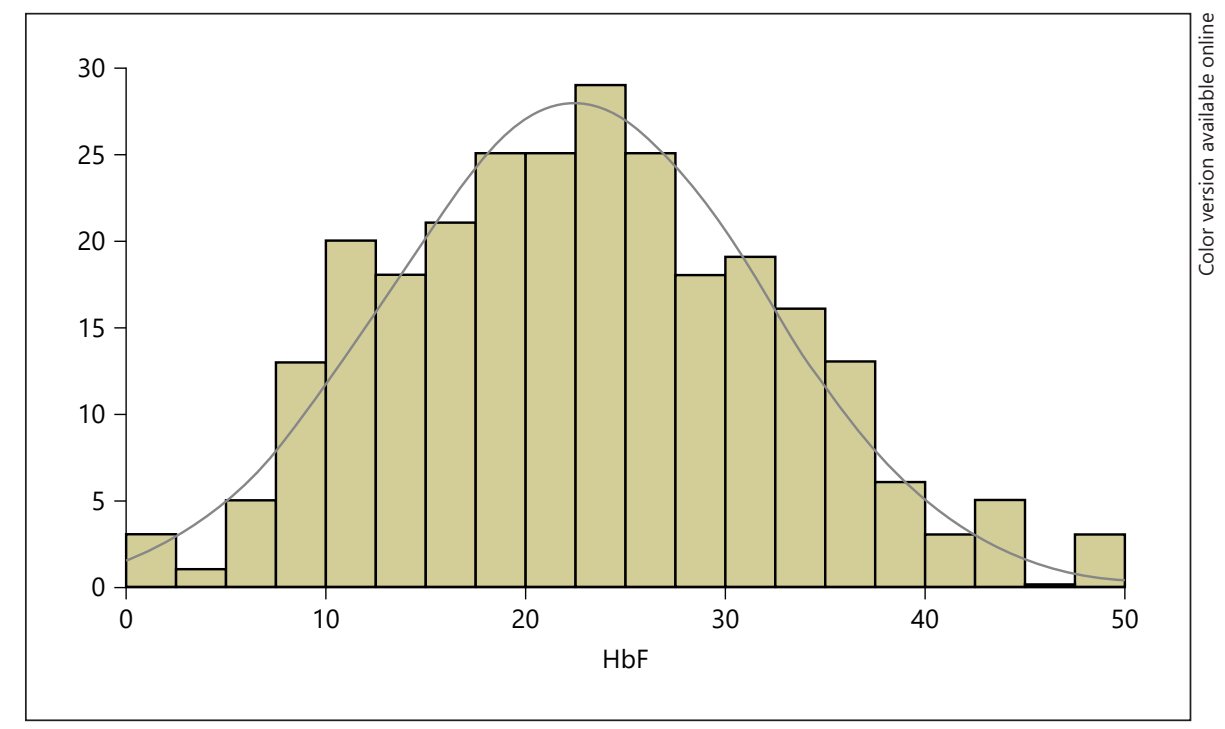

trait, and increased $\mathrm{HbF}$, although both factors have overall protective effects for many of the complications of the disease. It should be noted, however, that SCD can affect any organ in the body. The spleen bears an early burden of SCD pathology, and within the first few years of life, there is loss of spleen function, the so-called functional hyposplenia, and in the older patients, the recurrent infarction leads to autosplenectomy [16]. Thus, the patients are prone to infections with encapsulated organisms, notably pneumococcus, $H$. influenzae, and Sal- 
monella. Older patients are prone to end-organ damage and can present with chronic renal failure and lung disease.

\section{Biochemical and Clinical Evidence of $\mathrm{HbF}$ Amelioration in SCD}

The first evidence that $\mathrm{HbF}$ plays a protective role in SCD is that affected infants are asymptomatic until after $\sim 6$ months of life. Biochemical and clinical studies have confirmed the role of $\mathrm{HbF}$ in ameliorating the sickling process. The heterotetramer $\left(\alpha_{2} \gamma \beta^{S}\right)$ that is formed in the presence of $\gamma$ globin chains is much more soluble than the homotetramer $\left(\alpha_{2} \beta_{2}{ }_{2}\right)$; thus, there is an increase in the minimum gelling concentration of mixtures of $\mathrm{HbF}$ and HbS $[17,18]$. Moreover, the polymerization kinetics are modified with consequent increase in the delay time to gelation [19]. Irreversibly sickled cells have lower levels of $\mathrm{HbF}[20]$, and greater numbers of these cells produce increased viscosity of oxygenated whole SS blood [7].

Probably, the earliest clinical study of the influence of $\mathrm{HbF}$ on SCD phenotype was by Jackson et al. [21], who, in 1961, showed that their SS patients with $\mathrm{HbF}>12 \%$ had a significantly lower pathology index than those with levels $<10 \%$. Ali [22] described "a new form of sickle cell disease" in 6 Kuwaiti patients with HbSS from 2 families, and all but 1 had HbF levels $>20$. Although they were aged between 10 and 20 years, none had had any significant illnesses related to sickling [22]. Other studies from Eastern Saudi Arabia showed that patients with high $\mathrm{HbF}$ levels were less likely to have stroke, leg ulcers, and priapism $[23,24]$. Brittenham et al. [25], in 1977, reported 7 patients with HbSS from India, aged 1-63 years with very mild disease, one of whom was 28 years old with $\mathrm{HbF}$ of $29 \%$. There was, therefore, accumulating evidence of a mild SCD phenotype associated with high $\mathrm{HbF}$ levels among patients from Arabia and India. Studies from the USA have also consistently shown that patients with SCD who had relatively high HbF levels had fewer complications. Indeed, Powars et al. [26] showed that $\mathrm{HbF}$ of $\geq 20 \%$ is consistently associated with a lowered risk of major clinical events including end-organ damage.

\section{Genetic Control of HbF Expression}

\section{$\beta^{S}$-Globin Haplotype}

The $\beta^{S}$ haplotype is defined by a mapping of restriction endonuclease sites along the $\beta$-globin gene cluster. There are 4 major haplotypes, designated by the world regions to which they segregate. Thus, we have the Benin (BEN); Central African Republic (CAR), also referred to as Bantu (BAN); Senegal (SEN); and Arab/India (AI) [27]. These haplotypes also correspond to the severity of the phenotype, with SEN and AI being associated with mild disease [28]. Incidentally, these 2 haplotypes are the ones associated with persistence of $\mathrm{HbF}$ and are distinguished from the others by the Xmn-1 site at position - 158 in the HBG2 promoter region. The latter, designated rs7482144, is due to a $\mathrm{C} / \mathrm{T}$ polymorphism. Many studies have shown that individuals who carry the mutant $\mathrm{T}$ allele have persistent elevation of the $\mathrm{HbF}$ levels. CAR is associated with the most severe, while BEN has intermediate clinical severity.

\section{Other Quantitative Trait Loci}

Studies have shown that rs7482144 is responsible for $\sim 13-32 \%$ of the total $\mathrm{HbF}$ variance $[29,30]$. Indeed, there are also SCD and $\beta$-thalassemia patients who have elevated $\mathrm{HbF}$ levels despite being Xmn1-HBG2 C/C (or $-/-)$, with studies suggesting that some high $\mathrm{HbF}$ determinants segregated independently of the $H B B[31]$ gene. Using linkage and genome-wide association studies, other important QTL with strong $\mathrm{HbF}$ determinant single nucleotide polymorphisms (SNPs) have been described among patients with SCD and $\beta$-thalassemia from different parts of the world [29]. Some SNPs in the HMIP locus on chromosome $6 \mathrm{q} 23$ and the BCL11A on chromosome 2 , in addition to the $X m n 1$ site, together have been shown to account for up to $50 \%$ of the variance in $\mathrm{HbF}$ levels [32].

The mechanism of action of these SNPs is not quite clear. It has been suggested that the rs 7482144 has a direct effect on $H B G 2$ expression but may require the presence of other intermediary factors for action [29]. BCL11A correlates most strongly with $\mathrm{HbF}$ expression from the action of SNPs located within a region of about $14 \mathrm{~kb}$ in intron 2 of the gene [33-35]. The BCL11A genotype most associated with $\mathrm{HbF}$ expression correlates with reduced $B C L 11 A$ expression since it acts as a repressor and acts directly on the $H B B$ cluster, participating in $\mathrm{Hb}$ switching at different developmental stages [36]. The mode of action of the SNPs in the HMIP intergenic region is not quite clear but may be acting through regulation of the flanking genes - HBS1L and MYB [29, 37].

Apart from the 3 major QTL described, several others have been identified by linkage analysis and/or GWAS in different groups of patients, although they are still awaiting wide reproducibility. A chromosome 8-linked QTL has been proposed, first in an Asian Indian kindred and 
later confirmed in a study of twin pairs $[38,39]$. It has long been suspected that a codominant FC production locus is present on chromosome Xp22.2-22.3[40], which would explain the finding of higher $\mathrm{HbF}$ and $\mathrm{F}$-cell levels in adult female compared to male patients [41]. In a recent study, Liu et al. [42] identified SNPs in the SPARC, GJC1, EFTUD2, and JAZF1 genes as novel candidates associated with $\mathrm{HbF}$ levels.

\section{SCD in Kuwait}

Kuwait is a small country in the Northeast corner of the Arabian Peninsula, with a current population of $\sim 4.2$ million although Kuwaitis make up only $\sim 1.5$ million [43]. It is located in a desert area that was founded by immigrants from Eastern Saudi Arabia in the mid-18th century. Early settlers also included people from Iraq and Iran, hence the considerable gene admixture seen in this population [44]. The frequency of the $\mathrm{HbS}$ gene is estimated at about $3 \%$, although there is no newborn screening program. Since the first report by Ali [22] of a mild type of SCD in Kuwait, there have been many studies to document the phenotype and other characteristics of the disease in this population.

About $90 \%$ of the patients carry the AI haplotype either as homozygotes or as compound heterozygotes with the BEN haplotype [45]. They mostly have high HbF levels with a mean of $\sim 22 \%$ (Figs. 4, 5) [46, 47]. Interestingly too, there is a high frequency of the $\alpha$-thalassemia trait, found in $\sim 40 \%$ of the SCD patients [45]. This unique situation presents a natural model to study the phenotype in this genotypically homogeneous group. One important question is how much does the phenotype vary in this group of patients with such high HbF levels? Second, is there any correlation between $\mathrm{HbF}$ levels and observed complications?

While there are common trends in the overall phenotype, there is still considerable heterogeneity. In a 10-year study [48] of the causes of hospitalization, by far the most common cause was pain episodes in $63.2 \%$. Although most patients had 1-2 episodes over the course of the study, there was a small subset that had frequent $(>10)$ severe episodes. The next common causes of hospitalization were acute splenic sequestration (ASS) in 9.1\%, acute hemolysis in $8.8 \%$, and ACS in $6.6 \%$.

In an ongoing registry of SCD patients in Kuwait, we document the common phenotypes in patients who are being followed in major hospitals of the country. The most common $(\sim 33 \%)$ complication is gallstones, identi- fied either because the patients were symptomatic or on routine abdominal ultrasonography. However, the most severe morbidity that we encounter is due to avascular necrosis of the femoral head in $\sim 22 \%$ of registered patients.

The endothelial dysfunction subphenotypes, stroke, leg ulcers, and pulmonary hypertension are distinctly uncommon in Kuwaiti patients. Stroke is seen in $<1 \%$, which is similar to the report from the Eastern Province of Saudi Arabia. Leg ulcers are not encountered and priapism is also uncommon in $~ 3 \%$.

Further investigation of the CNS involvement showed mostly normal transcranial Doppler values among the patients [49]. Indeed, in a collaborative study with other countries in the region (Oman, Iraq, and UAE), transcranial Doppler values were generally normal [50]. It was also shown that silent brain infarcts are seen in about $3 \%$ of Kuwaiti children with SCD, while in adults, the prevalence is $\sim 20 \%[51,52]$. This is the reverse of what is seen among American patients, in whom the prevalence of silent infarcts is up to $20 \%$ in children but rare in adults [53]. We have also observed that neurocognitive function in these children is comparable to that in their unaffected siblings (unpublished data).

As a consequence of the common presentation with recurrent pain episodes, AVN is particularly common. In a 4-year prospective study, we showed that it is an unrelenting, progressive, chronic debilitating complication. The majority (65\%) of patients with AVN lesions on MRI showed progression over the study period, while the prevalence of AVN increased from 32.3 to 64\% [54]. Interestingly, $\mathrm{HbF}$ level and $\alpha$-thal trait did not influence the occurrence of AVN. The only associated factors were male gender and frequent vaso-occlusive episodes [55].

Unlike the situation among African and American children with SCD, bacterial infections, especially pneumococcal sepsis, are rare among Kuwaiti patients. Studies from other places have shown that splenic dysfunction contributes significantly [56] to the predisposition to infections in SCD. By the age of 2 years, most patients in America or Europe would have lost their spleen function (functional asplenia) [57]. Recurrent infarction causes autosplenectomy in the older children, usually starting from about 8 years [58]. However, among our patients in Kuwait, spleen function (phagocytosis and/or filtration) is retained in $>80 \%$ up to the age of 16 years and those with coexisting $\alpha$-thal trait were favored in this regard $[16,59]$. It is therefore not surprising that we see ASS among our adult patients [60]. 
SCD is indeed, relatively mild among Kuwaiti children; they are usually not symptomatic until the age of 3-4 years, probably because, up to this age, their $\mathrm{HbF}$ levels are $\geq 30 \%$. On the other hand, the phenotype in adults is quite severe. Thus, many of the complications encountered are more common among adults. The same pattern has been reported from Eastern Saudi Arabia by Alsultan et al. [61], with the adults having frequent ACS, ASS, osteonecrosis, gallstones etc. Therefore, although children are protected by the HbF levels, the cumulative effects of polymerization start to be evident in the older patients. It is this group of patients that have the crippling chronic organ changes.

\section{HbS $\beta$-Thalassemia and HbSD Phenotypes}

Although HbSS is the most common phenotype seen in SCD patients in Kuwait, other phenotypes are quite prevalent. This is because of the ancient migrations and genetic admixtures that have taken place in the region for millennia. HbS $\beta$-thalassemia is found in about $30 \%$ of Kuwaiti SCD patients, and depending on the $\beta$-thal mutation and the level of adult hemoglobin, it is classified as $S \beta^{0}$ or $S \beta^{+}$. In a previous study [62], we showed that the most common $\beta$-thal mutations are the $c d 39(\mathrm{C} / \mathrm{T})$ and IVS1-110 (G/A) for $\beta^{0}$ and $\beta^{+}$, respectively. Overall, the $\mathrm{S} \beta^{0}$ phenotype is similar to that in HbSS, and indeed, the rate of pain crises and splenic sequestration tend to be more frequent in $S \beta^{0}$ patients. This is despite the fact that the hematology, including $\mathrm{HbF}$ levels, is similar in the 2 phenotypes. The phenotype among patients with $S \beta^{+}$is also very variable depending on the $\beta$-thal mutation; patients with the IVS-I-6 $(\mathrm{C} / \mathrm{T})$ have very mild phenotype, while those with IVS-1-5 (G/A) are severe and virtually indistinguishable from the patients with $S \beta^{0}$ phenotype [62].

The third most common SCD phenotype in Kuwait is HbSD-Punjab. The patients carry the Xmn1 polymorphism on the $\mathrm{HbS}$ chromosome and have HbF levels of $>20 \%, \mathrm{HbD}$ of $30-45 \%$, and $\mathrm{HbS}$ of $25-30 \%$ [63]. In spite of this low level of HbS, the patients have a uniformly severe clinical course, much worse than in the average HbSS patient. It appears, therefore, that these patients are not protected by their high $\mathrm{HbF}$ levels, probably because the Glu/Gln substitution at codon 121 with a GAA/CAA at the DNA level creates strong pro-sickling bonds, with enhanced SD copolymerization that is not affected by FD hybrids. This theory is supported partially by the work of Adachi et al. [64].

\section{Response to Hydroxyurea in Kuwaiti Patients}

One-third of the patients in the Kuwait National SCD registry are on hydroxyurea ( $\mathrm{HU})$, mainly because of frequent severe pain episodes or anemia [60]. Patients with previous ACS or stroke are also started on HU at a nonescalating dose of $20 \mathrm{mg} / \mathrm{kg}$ per day. In a review of $38 \mathrm{pa}-$ tients on HU [65], we reported brisk clinical and hematological response, with a strongly significant positive correlation between the pre- and post-HU HbF levels with increases of 10 to $>400 \%$ over the baseline values.

There has always been a concern that $\mathrm{HU}$ may predispose these patients to osteonecrosis because of increased viscosity with elevated hematocrit following treatment. Our experience has, however, shown that this fear is not justified. We have followed many patients on HU for upwards of 15 years. Pre- and post-HU MRI of the hips have not suggested any increased predisposition to avascular necrosis of the femoral head; if anything, it tends to deter the appearance of new or progression of existing necrotic lesions $[54,55,66]$.

\section{Correlation of HbF to Clinical Phenotypes}

While it appears that as a group, patients with elevated $\mathrm{HbF}$ levels have a mild phenotype, we have not found a direct correlation between $\mathrm{HbF}$ and clinical phenotypes. There were no significant differences in $\mathrm{HbF}$ levels in patients with AVN, gallstones, spleen dysfunction, or ACS $[16,55,60]$. Accounting for this may be the fact that most of the patients have high HbF levels, so that this is no longer a discriminating factor; large prospective studies would be needed to validate this hypothesis. Moreover, apart from absolute $\mathrm{HbF}$ levels, its cellular distribution (F-cell number) is very important in determining the pathophysiological role of $\mathrm{HbF}$; the more pancellular, the better. Indeed, Steinberg et al. [67] suggested that rather than the total number of F-cells or the concentration of $\mathrm{HbF}$, the $\mathrm{HbF} / \mathrm{F}$-cell and the proportion of F-cells that have enough $\mathrm{HbF}$ to thwart $\mathrm{HbSpolymerization} \mathrm{is} \mathrm{the}$ most critical predictor of the likelihood of severe SCD. Thus, the HbF distribution among our patients should be examined from this point of view.

\section{Locally Relevant Genetic HbF Modifiers}

It is quite evident that, even among patients carrying the AI haplotype, there is still considerable variation in the HbF levels. The questions, therefore, are what are the 
relevant modifiers and are these similar to what have been reported from other parts of the world $[32,68-70]$ ? In particular, are the other widely recognized QTL $-B C L 11 A$ and the HMIP polymorphisms - relevant in this population or are there other novel modifiers still to be uncovered? Although the studies in this regard are sparse, there are some reports from Saudi Arabia and Kuwait. Ngo et al. [71] studied a group of patients from Saudi Arabia and noticed that they had a Gaussian distribution of $\mathrm{HbF}$ levels. They found that variants in the BCL11A accounted for $7.5 \%$ of $\mathrm{HbF}$ variance, while SNPs in the HMIP locus were not associated with $\mathrm{HbF}$. They posited that although the patients were all homozygous for the $\mathrm{HBB}$ cis-acting elements studied, these alone could therefore not account for the heterogeneity in the $\mathrm{HbF}$ levels. The experience from Kuwait is similar, where SNPs in these 2 loci did not significantly influenceHbF expression in response to $\mathrm{HU}$ [65]. The rs7482144, which characterizes the AI haplotype, is associated with high HBG2 expression, but its functional role has never been fully determined, and there may be other SNPs that are also important. Indeed, although Galarneau et al. [32] were able to replicate the association between this SNP and HbF levels, another SNP, rs10128556 in the HBG1 locus, was more strongly associated by 2 orders of magnitude among their American patients.

\section{Conclusions}

There is, indeed, overwhelming biochemical and clinical evidence that $\mathrm{HbF}$ ameliorates pathophysiological and clinical consequences of the sickling process. This is amply illustrated with the SCD phenotype among Kuwaiti patients, who uniformly have elevated HbF levels. What is also evident from this group of patients is that in spite of these elevated $\mathrm{HbF}$ levels, the clinical phenotype is still quite heterogeneous. The factors responsible for this are multiple and still to be fully understood. By the same token, the recognized cis- and trans-acting QTL that modify $\mathrm{HbF}$ expression have not been shown to be that important among patients with the Arab/Indian haplotype. This indicates that novel ethnocentric or haplotype-specific genetic factors are still to be discovered. This makes research in this area quite challenging and fascinating.

\section{Acknowledgements}

The author thanks all those who contributed to some of the work reported in this review, especially members of the Hematology Unit, Department of Pediatrics, Mubarak Al-Kabeer Hospital, Kuwait, and collaborators in the Department of Pediatrics, Faculty of Medicine, Kuwait University, especially Prof. Mohammad Haider and the technical staff.

\section{Statement of Ethics}

Not applicable.

\section{Conflict of Interest Statement}

The author declares no conflicts of interest.

\section{Funding Sources}

Some of the research reported was supported by Kuwait University Grants Nos. MK031, 034, 036, 01/08 and Kuwait Foundation for the Advancement of Science Grant No. 2013-1302-07.

\section{Author Contributions}

A.A. is solely responsible for this review article.

\section{References}

1 Asnani MR, Knight Madden J, Reid M, Greene LG, Lyew-Ayee P. Socio-environmental exposures and health outcomes among persons with sickle cell disease. PLoS One. 2017;12(4): $\mathrm{e} 0175260$.

2 Steinberg MH. Genetic etiologies for phenotypic diversity in sickle cell anemia. ScientificWorldJournal. 2009;9:46-67.

3 Sebastiani P, Solovieff N, Hartley SW, Milton JN, Riva A, Dworkis DA, et al. Genetic modifiers of the severity of sickle cell anemia identified through a genome-wide association study. Am J Hematol. 2010;85(1):29-35.
4 Driss A, Asare KO, Hibbert JM, Gee BE, Adamkiewicz TV, Stiles JK. Sickle cell disease in the post genomic era: a monogenic disease with a polygenic phenotype. Genomics Insights. 2009;2009(2):23-48.

5 Pauling L, Itano HA, Singer SJ, Wells IC, et al. Sickle cell anemia a molecular disease. Science. 1949;110(2865):543-8.

6 Weatherall DJ. Begininngs: the molecular pathology of hemoglobin. In: Provan D, Gribben J, editors. Molecular hematology. 2nd ed. Oxford: Blackwell Publishing; 2005.
7 Chien S, Usami S, Bertles JF. Abnormal rheology of oxygenated blood in sickle cell anemia. J Clin Invest. 1970;49(4):623-34.

8 Fronticelli C, Gold R. Conformational relevance of the beta6Glu replaced by Val mutation in the beta subunits and in the beta(1-55) and beta(1-30) peptides of hemoglobin S. J Biol Chem. 1976;251(16):4968-72.

9 Dykes GW, Crepeau RH, Edelstein SJ. Threedimensional reconstruction of the 14-filament fibers of hemoglobin S. J Mol Biol. 1979; 130(4):451-72. 
10 Carragher B, Bluemke DA, Gabriel B, Potel MJ, Josephs R. Structural analysis of polymers of sickle cell hemoglobin. I. Sickle hemoglobin fibers. J Mol Biol. 1988;199(2):315-31.

11 Wood WG. Haemoglobin synthesis during human fetal development. Br Med Bull. 1976; 32(3):282-7.

12 Kato GJ, Gladwin MT, Steinberg MH. Deconstructing sickle cell disease: reappraisal of the role of hemolysis in the development of clinical subphenotypes. Blood Rev. 2007;21(1): $37-47$.

13 Kato GJ, Hebbel RP, Steinberg MH, Gladwin MT. Vasculopathy in sickle cell disease: biology, pathophysiology, genetics, translational medicine, and new research directions. Am J Hematol. 2009;84(9):618-25.

14 Durante W, Johnson FK, Johnson RA. Arginase: a critical regulator of nitric oxide synthesis and vascular function. Clin Exp Pharmacol Physiol. 2007;34(9):906-11.

15 Kato GJ, Martyr S, Blackwelder WC, Nichols JS, Coles WA, Hunter LA, et al. Levels of soluble endothelium-derived adhesion molecules in patients with sickle cell disease are associated with pulmonary hypertension, organ dysfunction, and mortality. Br J Haematol. 2005;130(6):943-53.

16 Adekile AD, Tuli M, Haider MZ, Al-Zaabi K, Mohannadi S, Owunwanne A. Influence of alpha-thalassemia trait on spleen function in sickle cell anemia patients with high $\mathrm{HbF}$. Am J Hematol. 1996;53(1):1-5.

17 Bertles JF, Rabinowitz R, Döbler J. Hemoglobin interaction: modification of solid phase composition in the sickling phenomenon. Science. 1970;169(3943):375-7.

18 Bookchin RM, Nagel RL. Conformational requirements for the polymerization of hemoglobin S: studies of mixed liganded hybrids. J Mol Biol. 1973;76(2):233-9.

19 Nagel RL, Bookchin RM, Johnson J, Labie D, Wajcman H, Isaac-Sodeye WA, et al. Structural bases of the inhibitory effects of hemoglobin $\mathrm{F}$ and hemoglobin $\mathrm{A} 2$ on the polymerization of hemoglobin S. Proc Natl Acad Sci U S A. 1979;76(2):670-2.

20 Bertles JF, Milner PF. Irreversibly sickled erythrocytes: a consequence of the heterogeneous distribution of hemoglobin types in sickle-cell anemia. J Clin Invest. 1968;47(8): 1731-41.

21 Jackson JF, Odom JL, Bell WN. Amelioration of sickle cell disease by persistent fetal hemoglobin. JAMA. 1961;177:867-9.

22 Ali SA. Milder variant of sickle-cell disease in Arabs in Kuwait associated with unusually high level of foetal haemoglobin. Br J Haematol. 1970;19(5):613-9.

23 Perrine RP, Brown MJ, Clegg JB, Weatherall DJ, May A. Benign sickle-cell anaemia. Lancet. 1972;2(7788):1163-7.

24 Perrine RP, Pembrey ME, John P, Perrine S, Shoup F. Natural history of sickle cell anemia in Saudi Arabs. A study of 270 subjects. Ann Intern Med. 1978;88(1):1-6.
25 Brittenham G, Lozoff B, Harris JW, Sharma VS, Narasimhan S. Sickle cell anemia and trait in a population of southern India. Am J Hematol. 1977;2(1):25-32.

26 Powars DR, Chan L, Schroeder WA. The influence of fetal hemoglobin on the clinical expression of sickle cell anemia. Ann N Y Acad Sci. 1989;565:262-78.

27 Nagel RL, Fleming AF. Genetic epidemiology of the beta s gene. Baillieres Clin Haematol. 1992;5(2):331-65.

28 Powars DR. Sickle cell anemia: beta s-genecluster haplotypes as prognostic indicators of vital organ failure. Semin Hematol. 1991; 28(3):202-8.

29 Thein SL, Menzel S. Discovering the genetics underlying foetal haemoglobin production in adults. Br J Haematol. 2009;145(4):455-67.

30 Garner C, Tatu T, Reittie JE, Littlewood T, Darley J, Cervino S, et al. Genetic influences on F cells and other hematologic variables: a twin heritability study. Blood. 2000;95(1): 342-6.

31 Kulozik AE, Kar BC, Satapathy RK, Serjeant BE, Serjeant GR, Weatherall DJ. Fetal hemoglobin levels and beta (s) globin haplotypes in an Indian populations with sickle cell disease. Blood. 1987;69(6):1742-6.

32 Galarneau G, Palmer CD, Sankaran VG, Orkin SH, Hirschhorn JN, Lettre G. Fine-mapping at three loci known to affect fetal hemoglobin levels explains additional genetic variation. Nat Genet. 2010;42(12):1049-51.

33 Menzel S, Garner C, Gut I, Matsuda F, Yamaguchi $\mathrm{M}$, Heath S, et al. A QTL influencing $\mathrm{F}$ cell production maps to a gene encoding a zinc-finger protein on chromosome 2p15. Nat Genet. 2007;39(10):1197-9.

34 Sedgewick AE, Timofeev N, Sebastiani P, So JCC, Ma ESK, Chan LC, et al. BCL11A is a major $\mathrm{HbF}$ quantitative trait locus in three different populations with beta-hemoglobinopathies. Blood Cells Mol Dis. 2008;41(3): 255-8.

35 Uda M, Galanello R, Sanna S, Lettre G, Sankaran VG, Chen W, et al. Genome-wide association study shows BCL11A associated with persistent fetal hemoglobin and amelioration of the phenotype of beta-thalassemia. Proc Natl Acad Sci U S A. 2008;105(5): $1620-5$.

36 Sankaran VG, Menne TF, Xu J, Akie TE, Lettre G, Van Handel B, et al. Human fetal hemoglobin expression is regulated by the developmental stage-specific repressor BCL11A. Science. 2008;322(5909): 1839-42.

37 Lai MI, Jiang J, Silver N, Best S, Menzel S, Mijovic A, et al. Alpha-haemoglobin stabilising protein is a quantitative trait gene that modifies the phenotype of beta-thalassaemia. Br J Haematol. 2006;133(6):675-82.

38 Garner CP, Tatu T, Best S, Creary L, Thein SL. Evidence of genetic interaction between the beta-globin complex and chromosome $8 \mathrm{q}$ in the expression of fetal hemoglobin. Am J Hum Genet. 2002;70(3):793-9.
39 Garner C, Silver N, Best S, Menzel S, Martin C, Spector TD, et al. Quantitative trait locus on chromosome 8q influences the switch from fetal to adult hemoglobin. Blood. 2004; 104(7):2184-6.

40 Dover GJ, Smith KD, Chang YC, Purvis S, Mays A, Meyers DA, et al. Fetal hemoglobin levels in sickle cell disease and normal individuals are partially controlled by an X-linked gene located at Xp22.2. Blood. 1992;80(3): 816-24.

41 Thein SL, Craig JE. Genetics of $\mathrm{Hb}$ F/F cell variance in adults and heterocellular hereditary persistence of fetal hemoglobin. Hemoglobin. 1998;22(5-6):401-14.

42 Liu L, Pertsemlidis A, Ding LH, Story MD, Steinberg MH, Sebastiani P, et al. Original research: a case-control genome-wide association study identifies genetic modifiers of fetal hemoglobin in sickle cell disease. Exp Biol Med. 2016;241(7):706-18.

43 Review WP. Kuwait population 2020. 2019.

44 Abu-Hakima M. The modern history of Kuwait. London: Luzac; 1983.

45 Adekile AD, Haider MZ. Morbidity, beta S haplotype and alpha-globin gene patterns among sickle cell anemia patients in Kuwait. Acta Haematol. 1996;96(3):150-4.

46 Adekile A, Al-Kandari M, Haider M, Rajaa M, D'Souza M, Sukumaran J. Hemoglobin F concentration as a function of age in Kuwaiti sickle cell disease patients. Med Princ Pract. 2007; 16(4):286-90.

47 Adekile AD. Limitations of $\mathrm{Hb} \mathrm{F}$ as a phenotypic modifier in sickle cell disease: study of Kuwaiti Arab patients. Hemoglobin. 2011; 35(5-6):607-17.

48 Akar NA, Adekile A. Ten-year review of hospital admissions among children with sickle cell disease in Kuwait. Med Princ Pract. 2008; 17(5):404-8.

49 Asbeutah A, Gupta R, Al-Saeid O, Ashebu S, Al-Sharida S, Mullah-Ali A, et al. Transcranial Doppler and brain MRI in children with sickle cell disease and high hemoglobin F levels. Pediatr Blood Cancer. 2014;61(1):25-8

50 Adekile A, Hassan M, Asbeutah A, Al-Hinai M, Trad O, Farhan N. Transcranial doppler ultrasound in Peninsular Arab patients with sickle cell disease. J Ultrasound Med. 2019; 38(1):165-72.

51 Adekile AD, Yacoub F, Gupta R, Sinan T, Haider MZ, Habeeb Y, et al. Silent brain infarcts are rare in Kuwaiti children with sickle cell disease and high $\mathrm{Hb}$ F. Am J Hematol. 2002;70(3):228-31.

52 Marouf R, Gupta R, Haider MZ, Adekile AD. Silent brain infarcts in adult Kuwaiti sickle cell disease patients. Am J Hematol. 2003; 73(4):240-3.

53 Moser FG, Miller ST, Bello JA, Pegelow $\mathrm{CH}$, Zimmerman RA, Wang WC, et al. The spectrum of brain MR abnormalities in sickle-cell disease: a report from the cooperative study of sickle cell disease. AJNR Am J Neuroradiol. 1996;17(5):965-72. 
54 Gupta R, Adekile AD. MRI follow-up and natural history of avascular necrosis of the femoral head in Kuwaiti children with sickle cell disease. J Pediatr Hematol Oncol. 2004;26(6):351-3.

55 Adekile AD, Gupta R, Yacoub F, Sinan T, AlBloushi M, Haider MZ. Avascular necrosis of the hip in children with sickle cell disease and high $\mathrm{Hb} \mathrm{F}$ : magnetic resonance imaging findings and influence of alpha-thalassemia trait. Acta Haematol. 2001;105(1):27-31.

56 Powars DR, Pegelow CH. The spleen in sickle cell disease and thalassemia. Am J Pediatr Hematol Oncol. 1979;1(4):343-53.

57 Pearson HA, McIntosh S, Ritchey AK, Lobel JS, Rooks Y, Johnston D. Developmental aspects of splenic function in sickle cell diseases. Blood. 1979;53(3):358-65.

58 Powars DR. Natural history of sickle cell disease--the first ten years. Semin Hematol. 1975; 12(3):267-85.

59 Adekile AD, McKie KM, Adeodu OO, Sulzer AJ, Liu JS, McKie VC, et al. Spleen in sickle cell anemia: comparative studies of Nigerian and U.S. patients. Am J Hematol. 1993;42(3) $316-21$.

60 Adekile AD, Al-Sherida S, Marouf R, Mustafa $\mathrm{N}$, Thomas D. The sub-phenotypes of sickle cell disease in Kuwait. Hemoglobin. 2019; 43(2):83-7.

61 Alsultan A, Alabdulaali MK, Griffin PJ, Alsuliman AM, Ghabbour HA, Sebastiani P, et al. Sickle cell disease in Saudi Arabia: the phenotype in adults with the Arab-Indian haplotype is not benign. Br J Haematol. 2014;164(4): 597-604.

62 Adekile AD, Akbulut N, Azab AF, Al-Sharida $\mathrm{S}$, Thomas $\mathrm{D}$. The sickle $\beta$-thalassemia phenotype. J Pediatr Hematol Oncol. 2017;39(5): $327-31$.

63 Adekile A, Mullah-Ali A, Akar NA. Does elevated hemoglobin F modulate the phenotype in Hb SD-Los Angeles? Acta Haematol. 2010; 123(3):135-9.

64 Adachi K, Kim J, Ballas S, Surrey S, Asakura $\mathrm{T}$. Facilitation of $\mathrm{Hb} \mathrm{S}$ polymerization by the substitution of Glu for Gln at beta 121. J Biol Chem. 1988;263(12):5607-10.

65 Adekile A, Menzel S, Gupta R, Al-Sharida S, Farag A, Haider M, et al. Response to hydroxyurea among Kuwaiti patients with sickle cell disease and elevated baseline $\mathrm{HbF}$ levels. Am J Hematol. 2015;90(7):E138-9.

66 Adekile AD, Gupta R, Al-Khayat A, Mohammed A, Atyani S, Thomas D. Risk of avascular necrosis of the femoral head in children with sickle cell disease on hydroxyurea: MRI evaluation. Pediatr Blood Cancer. 2019;66(2): e27503.

67 Steinberg MH, Chui DH, Dover GJ, Sebastiani P, Alsultan A. Fetal hemoglobin in sickle cell anemia: a glass half full? Blood. 2014; 123(4):481-5.

68 Lettre G, Sankaran VG, Bezerra MA, Araújo AS, Uda M, Sanna S, et al. DNA polymorphisms at the BCL11A, HBS1L-MYB, and beta-globin loci associate with fetal hemoglobin levels and pain crises in sickle cell disease. Proc Natl Acad Sci U S A. 2008;105(33): 11869-74.

69 Makani J, Menzel S, Nkya S, Cox SE, Drasar E, Soka D, et al. Genetics of fetal hemoglobin in Tanzanian and British patients with sickle cell anemia. Blood. 2011;117(4):1390-2.

70 Menzel S, Thein SL. Genetic modifiers of fetal haemoglobin in sickle cell disease. Mol Diagn Ther. 2019;23(2):235-44.

71 Ngo D, Bae H, Steinberg MH, Sebastiani P, Solovieff N, Baldwin CT, et al. Fetal hemoglobin in sickle cell anemia: genetic studies of the Arab-Indian haplotype. Blood Cells Mol Dis. 2013;51(1):22-6. 